\title{
Foreign Direct Investment: The Canadian Experience
}

\author{
Nuno Carlos Leitão (Corresponding author) \\ ESGTS, Polytechnic Institute of Santarém \\ Complexo Andaluz Apartado 295 2001-904 Santarém, Portugal \\ Tel: 351-243-303 200 E-mail: nunocarlosleitao@gmail.com
}

\begin{abstract}
The Canadian economy has been a net recipient of foreign direct investment (FDI). The free-trade agreements (FTA and NAFTA) have had to attract more inward FDI. This study examines the determinants of foreign direct investment (FDI) between Canada and EU15, Brazil and Japan in the period 1995-2007. The purpose of this paper is to analyze the impact of variables, such as, market size, labour costs, trade openness and economic stability. The manuscript applies a static and dynamic panel data approach (Fixed Effects estimator and GMM system estimator). In contrast to previous studies, this paper used a dynamic panel data to solve the problems of serial correlation and endogeneity.
\end{abstract}

The empirical results indicate that the market size, trade openness are significant factors to explain inward FDI to Canada. These results indicate that the FDI attracting will be influence by market size.

The wage and taxes are also statistically significant. In other words, the macroeconomic stability influences the decision of foreign investors.

Keywords: Foreign direct investment, panel data, Canada

\section{Introduction}

With globalization, many nations have liberalized their trade policies and removed trade barriers. The transaction costs decreased and the integration of economies has contributed to increases in foreign direct investment (FDI). As referred by Rugman and Verbeke (2008), FDI is one channel for the globalization of world economy. Multinational enterprises (MNEs) specifically acquire news markets, because these firms have specific advantages, or they want to acquire localization advantages (OLI paradigm - O: ownership, L: localization, I: internalization, Dunning, 1992, and Dunning and Lundan, 2008).

There is a vast literature of FDI flows. The literature explains these flows based on host advantages countries. A wide variety of views have been used to explain the importance of attracting FDI to the Canadian economy. There are basically two arguments for attracting inward FDI to Canada. The first is based on the elimination of trade barriers. The second is more common that inward investment is an indicator of openness, and this is crucial to economic growth.

This paper analyses the determinants of inward FDI in Canada for the period 1995 to 2007. This study uses country-specific characteristics (per capita income, market size, trade openness, labour costs, and the level of economic stability). The countries selected are the United States (US), the European Union (EU15), Brazil and Japan.

The manuscript uses a panel data approach. In panel data, pooled ordinary least squares (OLS), fixed effects (FE) and random-effects (RE) estimators are used in the study. The RE estimator was excluded because the sample is not random. Furthermore, the Hausman test rejects the null hypothesis of RE versus FE. We also introduce a dynamic panel data. The estimator used (GMM-SYS) estimator permits the researchers to solve the problems of serial correlation, heteroskedasticity and endogeneity of some explanatory variables. These econometric problems were resolved by Arellano and Bond (1991), Arellano and Bover (1995) and Blundell and Bond (1998, 2000), who developed the first-differenced GMM (GMM-DIF) estimator and the GMM system (GMM-SYS) estimator. The GMM-SYS estimator is a system containing both first-differenced and level equations. The GMM- SYS estimator is an alternative to the standard first-differenced GMM estimator. The GMM-SYS estimator also controls for the endogeneity of the explanatory variables.

To estimate the dynamic model, we applied the methodology of Blundell and Bond (1998, 2000), and Windmeijer (2005) to a small sample correction to have corrected standard errors of Blundell and Bond $(1998,2000)$ but correcting the estimated standard errors using the Windmeijer correction. The structure of the paper is a follows. The next section presents the trend of inward FDI in the Canadian economy. In section 3 the literature is reviewed. In Section 4, we present the econometric model. Section 5 presents the estimation results. Section 6 concludes. 


\section{Foreign Direct Investment in Canada}

The FDI in Canada improved only after the implementation of free-trade agreements, specifically the North American Free Trade Agreement (NAFTA). The Canadian economy has been a net recipient of FDI. As Table 1 shows, the major Canadian investors in terms of inward FDI in Canada are US (57.6 per cent), United Kingdom (10.9 per cent), Netherlands (6.3 per cent), Switzerland ( 2.8 per cent), Japan ( 2.7 per cent), and Germany (2.1 per cent). The EU countries investments represent more 30 per cent of Canadian inflows.

\section{Literature Review and Empirical Studies}

There is an excellent literature of Canadian FDI inflows (Caves and Reuber, 1971; Cameron, 1998; Rugman, 1980, and Rugman, 1990). The study of Globerman and Shapiro (1999) analyses the impact of government policies over the period 1990-1995. The author concluded that Canada's free-trade agreements permitted an increase in the level of FDI. Hejazi and Pauly (2003) analyze the motivations for FDI and domestic capital formation based on the Canadian experience. The authors demonstrate that increased inward FDI contributes to domestic capital formation, production, and economic growth. Hejazi and Pauly (2003) concluded that inward FDI could be explained, or motivated by natural resources. This conclusion is according to the OLI paradigm (Dunning, 1992 and Dunning and Lundan, 2008).

The literature on FDI began in 1960s and 1970s with Hymer (1960), Kindleberger (1969) and Caves (1971). Dunning (1981) with the eclectic theory of FDI, suggested that internalization could explain the movements of MNEs. The author introduced the eclectic paradigm in 1992.

The OLI paradigm explains why the investors invest in host country. Ownership advantages could explain free access to technology and new products. Firms have ownership characteristics (inputs) as in patents, brand, human resources and financial assets.

Localization advantages are explained by the motivation of FDI. In this topic, we need to think about efficiency, that J. Dunning calls movement of production where there are lower input costs (outsourcing of production). The author also analyses the foreign market proximity (strategic asset-seeking). In this case Dunning explains the relationships between foreign market proximity and exports, or foreign market proximity and new production (i.e, if it is better to move production).

The economic factors, such as, market size, growth rate, labour costs, labour skills and per capita income have been considered as explanatory variables in econometric models.

Recently the researchers of international foreign investment as in, Jeon and Rhee (2008), Maniam (2007), Skabic, and Orlic (2007), and Rodriguez and Pallas (2008) explain the determinants of FDI by market size, labour costs, labour skills, openness, risks, macroeconomic and political stability and other factors. Other variables include knowledge capital (Markusen 2001), human capital (Sun et al.2002), similar language and cultural levels (Dunning 1981).

It is important to recognize that the relative importance of FDI determinants depend on the motive, the type of investment (vertical FDI export-oriented or horizontal FDI market access-oriented) and the investor's strategy. Vertical FDI is explained by lower production costs (cheap labour, tax incentives and physical infrastructures). For horizontal FDI the size of host country and its growth is the most important (Helpman 2006). Multinationals sometimes create export platforms in low-cost countries (localization advantages) from which they serve developed countries around the world.

Jeon and Rhee (2008) analyse the determinants of Korea's FDI from the US for the period 1980- 2001. The authors conclude that Korea's FDI inflows from the US have a significant association with real exchanges rates, relative wages costs and interest rate differentials using a pooled OLS estimation.

Maniam (2007) used an OLS estimator to analyse the determinants of FDI in Latin America for the period 1975-2003. The author concluded that FDI has increased rapidly in Latin America. According to Maniam (2007:13) there are relationships between the economic variables and investors expectations, latter on the host countries need to develop better their strategies.

Skabic and Orlic (2007) apply the FE estimator for the period 1993 to 2005 for Central and Eastern European countries and Western Balkan counties. The work of Skabic and Orlic (2007: 348) demonstrates that Western Balkan countries should make additional efforts in order to cut corruption in their economies to become attractive to FDI.

Rodríguez and Pallas (2008) utilize a panel data to examine the determinants of FDI in Spain for the period 1993-2002. Rodríguez and Pallas (2008) consider that human capital and the export potential of the sector are the most important determinants.

The recent literature as in Naudé and Krugell (2007), and Alguacil et al. (2008) consider that FDI is a dynamic 
phenomenon.

Nudé and Krugell (2007) specify a dynamic panel data (GMM-DIF) proposed by Arellano and Bond (1991). The study of Naudé and Krugell (2007) demonstrates that African policy makers have been intensifying their attempts to attract FDI, researching into the determinants of FDI in Africa.

\section{Econometric Model}

The dependent variable is Canadian inward FDI. The explanatory variables are country-specific characteristics. The data for the explanatory variables are sourced from the Work Bank (2009) and from the World Development Indicators. The source for the dependent variable, inward FDI, is from the Organization of Economic Cooperation and Development (OECD) International Direct Investment Database.

\subsection{Static and Dynamic Panel Data Models}

The static panel data models were estimated with pooled ordinary least squares (OLS), fixed effects (FE) and random effects (RE) estimators. The F statistics tests the null hypothesis of same specific effects for all countries. If we accept the null hypothesis, we could use the OLS estimator. The Hausman test can decide which model is better: random effects (RE) versus fixed effects (FE). For purposes of comparison with dynamic model, the FE model was selected because it avoids the inconsistency due to correlation between the explanatory variables and the country-specific effects. In the FE model, all explanatory variables are potentially correlated with the effects.

This manuscript estimates the dynamic panel data model using GMM-System estimator. The system GMM estimator (GMM-SYS) was proposed by Arellano and Bond (1995) and Blundell and Bond (1998, 2000). The GMM estimator permits efficient estimates to be obtained.

\subsection{Explanatory variables}

The paper uses the following explanatory variables in logs:

- Market size, LogGDP is the logarithm of the absolute value of GDP per capita (PP, in current international dollars) for Canada. According to the literature (Globerman and Shapiro 1999, Naudé and Krugell, 2007, and Maniam, 2007) we expect positive sign.

- Trade Openness, LogTRADE is a proxy for trade openness. It is the logarithm of exports/GDP ratio. Sun et al. (2001), Skabic, and Orlic (2007) found a positive sign.

- Taxes, LogTAXEs, is the logarithm of Canadian tax levels. The taxes levels of the host country manipulate the decision of foreign investors. The studies of Kemsley (1998) and Billington (1999) found a correlation between taxes rates and FDI.

- Inflation, LogINF is the logarithm of Canadian inflation rate. The inflation rate is used to measure the level of economic stability. We expect negative sign (Naudé and Krugell, 2007).

- Real wages, LogW is the logarithm of Canadian real wages. Countries with lower wages would attract more FDI. Globerman and Shapiro (1999) Skabic, and Orlic (2007) found a negative correlation between labour costs and FDI.

4.3 Model specification

$$
F D I_{i t}=\beta_{0}+\beta_{1} X_{i t}+\delta t+\eta_{i}+\varepsilon_{i t}
$$

Where $F D I_{i t}$ is Canadian foreign direct investment inflows, $\mathrm{X}$ is a set of explanatory variables. All variables are in the logarithm form; $\eta \mathrm{i}$ is the unobserved time-invariant specific effects; $\delta t$ captures a common deterministic trend; $\varepsilon_{i t}$ is a random disturbance assumed to be normal, and identical distributed (IID) with $\mathrm{E}\left(\varepsilon_{i t}\right)=0$; Var $\left(\varepsilon_{i t}\right)=\sigma^{2} \succ 0$.

The model can be rewritten in the following dynamic representation:

$$
F D I_{i t}=\rho F D I_{i t-1}+\beta_{1} X_{i t}-\rho \beta_{1} X_{i t-1}+\delta t+\eta_{i}+\varepsilon_{i t}
$$

\section{Estimation Results}

In this section we present the results with country characteristics as explanatory variables. We include in this regression the EU15, US, Brazil and Japan. Table 2 presents the estimation using the FE estimator. The general performance of the model is satisfactory. All variables are statistically significant and the explanatory power of FDI regression is very high (Adjusted $\mathrm{R}^{2}=0.932$ ). The coefficient for market size (GDP) is positive and significant at the 10 per cent level. Globerman and Shapiro (1999) and Maniam (2007) found a positive sign. This result shows that 
the FDI attracting will be influence by market size.

The variable LogTRADE (trade openness) has a significant and positive effect on inward FDI. This result is according to the literature (Globerman and Shapiro,1999; Hejazi and Pauly,2 003). Skabic and Orlic (2007) also found a positive sign. This result demonstrates that the trade partners and the openness of economy are an important vehicle to expand FDI.

The coefficient of LogTAXES (taxes levels) is negative as expected and is significant at the 1 per cent level. This result demonstrates the importance of the taxes levels of the host country. In the other words, the taxes levels of host country influence the decision of foreign investors.

For the variable LogINF (inflation) that is used to evaluate the economic stability, the result confirms this.

The lower wages in Canada are an important factor to attracting FDI. As in Globerman and Shapiro (1999), and Skabic and Orlic (2007), we found a negative sign.

Table 3 presents the estimation using the GMM-system (GMM-SYS) estimator. The model presents consistent estimates, with no serial correlation ( $\mathrm{m} 1, \mathrm{~m} 2$ statistics). The specification Sargan test show that there are no problems with the validity of instruments used. The equation presents five significant variables $\left(\operatorname{LogFDI}_{t-1}\right.$, LGDP, LogTRADE, LogTAXES and LogW). The GMM system estimator is consistent if there is no second-order serial correlation in the residuals ( $\mathrm{m} 2$ statistics). The dynamic panel data is valid if the estimator is consistent and the instruments are valid. We used the criterion of Windmeijer (2005) to small sample correction. The instruments in levels used are $\operatorname{LogFDI}(2,7), \operatorname{LogGDP}(2,7), \operatorname{LogTRADE}(2,7)$ for first differences. For levels equations, the instruments are used first differences all variables t-1. As expected, the lagged dependent variable is positive.

The variable, LogGDP (income per capita), used also by Globerman and Shapiro (1999), has a significant and predicted positive effect on FDI. A study of Rodriguez and Pallas (2008) analyse the case of Spain also found a positive sign. The proxy for tax levels (LogTAXES) presents a negative expected sign. The studies of Kemsley (1998) and Billington (1999) also found a negative correlation between taxes rate and FDI. According to this result, we can conclude that taxes levels of the host country manipulate the decision of foreign investors. The variable, real wages in $\log (\log \mathrm{W})$ presents a negative sign, confirming the theoretical forecast proposed by the literature. Skabic and Orlic (2007) found a negative correlation between labour costs and FDI.

\section{Conclusion}

In recent years, there has been a significant growth of FDI literature. Most studies seek to explain the determinants of FDI inflows in the context of host countries.

The objective of this study was to analyze some of the determinants of inward FDI in Canada. Comparing our findings with other empirical studies, we obtained similar results. Econometrics estimations support the hypothesis formulated. Our results are robust with static and dynamic panel data.

The US, UK, Netherlands, France, Switzerland, and Brazil are the major investors.

As our result show, FDI has a dynamic nature. To understand this phenomenon we applied a dynamic panel data and we compared the results with a static panel data. The lagged inward FDI variable presents an expected positive sign.

In view of the results, it would seem evident that the economic policy in Canada towards attracting FDI is an important factor. The market size (LogGDP) has been statistically significant. This result is in line with those obtained by Globerman and Shapiro (1999) and Naudé and Krugell (2007).

The relative costs (real wages), which is a fundamental element of increased per-worker labour productivity is also a significant determinant of inward FDI in Canada.

In addition to productivity, a further indicator of competitiveness is trade openness, which reveals a positive impact on inward FDI.

The macroeconomic factors used that measure the situation of Canada (levels of taxes, and inflation) are statistically significant with negative signs for different estimators (FE and GMM-SYS).

This study has however some limitations. For future research, we need to include industry characteristics into the analysis in order to investigate the impact of industry -specific factors on inward FDI, and other control variables: language and cultural similarity, innovation, technology and human capital.

Acknowledgments: This paper has benefited from helpful of comments made by two anonymous referees.

\section{References}

Alguacil, M, Cuadros, A, and Orts, V. (2008). EU Enlargement and Inward FDI, Review of Development Economics, 
$12(3), 594-604$.

Arellano, M. and Bond, S. (1991). Some Test of Specification for Panel Data: Monte Carlo Evidence and An Application to Employment Equations, Review of Economic Studies 58, (2), 277-297.

Arellano, M. and Bover, O. (1995). Another Look at Instrumental Variable Estimation of Error- Components Models, Journal of Econometrics, 68, (1), 29-51.

Billington N. (1999). The Location of Foreign Direct Investment: An Empirical, Applied Economics 31, 65-76.

Blundell, R and Bond, S. (1998). Initial Conditions and Moment Restrictions in Dynamic Panel Data Models, Journal of Econometrics Review, 87, (1), 115-143.

Blundell, R and Bond, S. (2000). GMM Estimation with Persistent Panel Data: An Application to Production Functions, Econometrics Review, 19 (3), 321-340.

Cameron, R. (1998). Intra-firm trade of Canadian-based transnational companies, Industry Canada Research Publications Program, Working Paper 26, Industry Canada, Ottawa.

Caves, R. (1971). The Industrial Economics of Foreign Investment, Economics, 18, 1-27.

Caves, R, and Reuber, G. (1971). Capital Transfer and Economy Policy: Canada,1951-1962, Harvard University Press: Cambridge, MA.

Dunning, J. (1981). Explaining the International Direct Investment Position of Countries: Towards a Dynamic Development Approach, Weltwritschaftliches Archiv, 119, 30-64.

Dunning, J. (1992). Trade, Localization and Economic Activity and the Multinational Enterprise: A Search for an Eclectic Approach, in Dunning, J. (ed.) The United Nations library on transnational corporations- the theory of transnational corporation, 1, New York: Routledge 183-218.

Dunning, J. and Fortanier, F. (2007). Multinational Enterprise and the New Development Paradigm: Consequences for Host Country Development, Multinational Business Review, 15,1: 25-45.

Dunning, J. and Lundan, M. (2008). Institutions and the OLI paradigm of the multinational enterprise, Asia Pacific Journal of Management, 25, 573-593.

Globerman, S, and Shapiro, D. (1999). The impact of government policies on foreign direct investment: The Canadian Experience, Journal of International Business Studies, 30 (3), 513-533.

Helpman, E. (2006). Trade, FDI and the organization of firms, Journal of Economic Literature, 44, 568-630.

Hejazi, W, and Pauly, P. (2003). Motivations for FDI and domestic capital formation, Journal of International Business Study, 34 (3), 282-289.

Hymer S. (1960). The International Operations of National Firms: A Study of Direct Foreign Investment, MIT Press, Cambridge, MA.

Kemsley D. (1998). The Effect of Taxes on Production Location, Journal of Accounting Research 36, 321-341.

Kindleberger, C, P. (1969). American Business Aboard Six Lectures on Direct Investment, New Haven: Yale University Press.

Jeon, B.and Rhee, S. (2008). The Determinants of Korea's Foreign Direct Investment from the United States, 1980-2001: An Empirical Investigation of Firm-Level Data, Contemporary Economic Policy, 26 (1), 118-131.

Markusen, J. (2001). Contracts, intellectual property rights, and multinational investment in developing countries, Journal of International Economics, 53(1) 189-204.

Maniam, B. (2007). An Empirical Investigation of US. FDI in Latin America, Journal of International Business Research, $6(2), 1-15$.

Naudé, W and Krugell, W. (2007). Investigation as Determinants of Foreign Direct Investment in Africa using Panel Data. Applied Economics, 39, 1223-1233.

Rodríguez, X. and Pallas, J. (2008). Determinants of Foreign Direct Investment in Spain, Applied Economics, 40, 2443-2450.

Rugman, A. (1980). Multinationals in Canada: Theory, Performance and Economic Impact, Nijhohff Publishing:Boston.

Rugman, A. (1990). Multinationals and Canada-United States Free Trade, University of South Carolina Press: Columbia, South Carolina. 
Rugman, A. and Verbeke, A. (2008). A New Perspective and the Regional and Global Strategies of Multinational Services Firms, Management International Review 2 48,4, 397-411.

Sun, Q, Tong, W, and Yu Q. (2002). Determinants of Foreign Direct Investment Across China, Journal of International Money and Finance, 21, 79-113.

Skabic, I. and Orlic, E. (2007). Determinants of FDI in CEE and Western Balkman Countries (Is Accession to the EU important for Attracting FDI?), Economic and Business Review, 9 (4), 333-350.

Windmeijer, F.2005. A finite sample correction for the variance of linear effcient two-step GMM estimators, Journal of Econometrics, 26 (1), 25-51.

Table 1. Major Sources of Foreign Direct Investment in Canada, 2007

\begin{tabular}{|l|c|c|}
\hline Regions/Countries & \$ billion & \% of total \\
\hline United States & $\mathbf{2 8 8 . 6}$ & $\mathbf{5 7 . 6}$ \\
\hline Europe & $\mathbf{1 5 7 . 5}$ & $\mathbf{3 1 . 4}$ \\
\hline United Kingdom & 54.8 & 3.9 \\
\hline France & 17.4 & 6.3 \\
\hline Netherlands & 31.5 & 2.1 \\
\hline Germany & 10.5 & 2.8 \\
\hline Switzerland & 13.8 & $\mathbf{6 . 5}$ \\
\hline Asia-Pacific & $\mathbf{3 2 . 7}$ & 2.7 \\
\hline Japan & 13.4 & 0.7 \\
\hline Australia & 3.3 & $\mathbf{3 . 6}$ \\
\hline Latin America and Caribbean & $\mathbf{1 8 . 2}$ & 2.6 \\
\hline Brazil & 12.8 & 0.6 \\
\hline Bermuda & 3.0 & $\mathbf{0 . 8}$ \\
\hline Others & $\mathbf{3 . 9}$ & $\mathbf{1 0 0 . 0}$ \\
\hline Total & $\mathbf{5 0 0 . 9}$ & \\
\hline
\end{tabular}

Source: Statistics Canada data.

Table 2. The determinants of foreign direct investment (FDI): Fixed Effects estimator

\begin{tabular}{|l|c|c|c|c|}
\hline Variables & Coefficient & t-statistics & significance & Expected Signs \\
\hline LogGDP & 6.863 & $(1.912)$ & $*$ & $(+)$ \\
\hline LogTRADE & 2.012 & $(2.518)$ & $* *$ & $(+)$ \\
\hline LogTAXES & -0.415 & $(-3.009)$ & $* * *$ & $(-)$ \\
\hline LogINF & -0.567 & $(-2.119)$ & $* *$ & $(-)$ \\
\hline LogW & -35.906 & $(-4.504)$ & $* * *$ & $(-)$ \\
\hline Observations & 217 & & & \\
\hline Adj. $\mathrm{R}^{2}$ & 0.932 & & & \\
\hline
\end{tabular}

T- statistics (heteroskedasticity corrected) are in round brackets.

$* * * / * * / *$ - statistically significant at the $1 \%, 5 \%$ and $10 \%$ levels. 
Table 3. The determinants of foreign direct investment (FDI): GMM-SYS estimator

\begin{tabular}{|l|c|c|c|c|}
\hline Variables & Coefficient & t-statistics & significance & Expected Signs \\
\hline LogFDI $_{\mathrm{t}-1}$ & 0.587 & $(5.56)$ & $* * *$ & $(+)$ \\
\hline LogGDP & 5.909 & $(2.32)$ & $* *$ & $(+)$ \\
\hline LogTRADE & 0.964 & $(1.80)$ & $*$ & $(+)$ \\
\hline LogTAXES & -0.224 & $(-1.66)$ & $*$ & $(-)$ \\
\hline LogINF & -0.383 & $(-1.60)$ & & $(-)$ \\
\hline LogW & 15.503 & $(1.75)$ & $*$ & $(-)$ \\
\hline C & -0.090 & $(-0.762)$ & & \\
\hline M1 & $-1.254[0.210]$ & & & \\
\hline M2 & $-0.5514[0.581]$ & & & \\
\hline Sargan & $7.672[1.000]$ & & & \\
& Df=84 & & & \\
\hline Observations & 177 & & & \\
\hline
\end{tabular}

T-statistics (heteroskedasticity corrected) are in round brackets. The null hypothesis that each coefficient is equal to zero is tested using second -step robust standard error. T-statistics (heteroskedasticity corrected) are in round brackets. **, and * indicates statistically significance, respectively at the 5\%, and $10 \%$ level. P-values are in square brackets. Year dummies are included in all specifications (this is equivalent to transforming the variables into deviations from time means, i.e. the mean across the fourteen countries for each period). M1 and M2 are tests for first-order and second-order serial correlation in the first-differenced residuals, asymptotically distributed as $\mathrm{N}(0,1)$ under the null hypothesis of no serial correlation (based on the efficient two-step GMM estimator). Sargan is a test of the over-identifying restrictions, asymptotically distributed as $\chi^{2}$, under the null of instruments' validity (with two-step estimator).***/**- statistically significant, respectively at the $1 \%$ $5 \%$ levels. 